\title{
オクタデカンー $\mathrm{CO}_{2}$ およびオクタデカンーエタン系の $25^{\circ} \mathrm{C}, 40^{\circ} \mathrm{C}$ における 高圧相平衡
}

\author{
大垣 一 成・塚 原 逸 朗 \\ 片 山俊 \\ 大阪大学基䃈工学部 化学工学科*
}

\begin{abstract}
最近注目されてきている超臨界流体を利用した抽出分離の基礎的研究として, 溶媒成分に $\mathrm{CO}_{2}$, 工 タンを選び，オクタデカンを溶質成分とした各二成分系の高压相平衡関係を, 各溶媒成分の臨界温度 と溶質成分の融点を同時にはさんだ $25^{\circ} \mathrm{C}$ および $40^{\circ} \mathrm{C}$ で実測した．測定に用いた実験装置は新た に作製した流通方式であり，平衡組成は重量分析法によった，各混合系の臨界軌跡を推算し，各実験 操作条件に対応する相平衡関係が固気, 気液, 液液いずれの異相間の平衡関係なのかを考察した後, 気液および液液の平衡関係に対しては両相に直接 Soave-Redlich-Kwong 状態式を適用して実験 データの相関を試みた。一方固相を含も場合については，固相に適当な仮定を固き，流体相に対して のみ Soave-Redlich-Kwong 状態式を適用して相関した。いずれの場合もほぼ満足できる相関結 果を得た.

本研究で取り扱った混合系では，溶媒成分の臨界温度より低温の $25^{\circ} \mathrm{C}$ における溶質成分の溶解度 が超臨界温度におけるそれよりもかなり大きくなる圧力範囲の存在が確認できた。この特徴を利用し た新しい分離技術の開発が期待される.
\end{abstract}

\section{緒言}

最近，食品，石油，医薬品化学等の工業プロセスに㧊 いて, 超臨界および臨界点近傍に打ける高圧流体の急激 な物性変化を利用したいわゆる超臨界抽出分離技術（以 降 SCE と呼ぶ) の開発が注目されてきている。とりわ け, 食品打よび医薬品化学等, ファインケミカルの分野 では抽出成分にクリーンさを要求されることも手伝って SCE に対する期待は非常に大きい。

本研究ではこうした点を考慮し, 天然動植物油中に炭 素数 18 の高級脂肪酸およびそのエステルが多く存在す ることから，まずその物性值が比較的良く知られている オクタデカンと, $\mathrm{CO}_{2}$ およびェタンの二成分系の高圧 相平衡関係を $25^{\circ} \mathrm{C}, 40^{\circ} \mathrm{C}$ で実測した。この 2 つの温 度は, オクタデカンの融点 $\left(28.2^{\circ} \mathrm{C}\right)$ をはさみ, 同時に 両抽出溶媒成分の臨界温度 $\left(\mathrm{CO}_{2}: 31^{\circ} \mathrm{C}\right.$, エタン: $\left.32.2^{\circ} \mathrm{C}\right)$ をはさむことから, 固液, 固気, 気液, 液液等さまざま な異相間の平衡関係の存在が予想され熱力学的にも興味 深い.

\section{1. 実験測定装置および方法}

本研究で作製した実駼装置の概略図を Fig. 1 に示す. この装置の特徵は流通法であることと平衡組成を重量分 析により測定する点にある. 図中の高圧ポンプ (B) には 島津製作所製の液体クロマトグラフ 用ポンプ LC $-3 \mathrm{~A}$

* $\overline{\text { 干 } 560}$ 豊中市待兼山町 1-1
に定圧操作が可能となる制御器を取り付けて使用した. 最大圧力は 400 気圧で圧力制御は \pm 5 気圧以内であっ た. 圧力調整器 (D) の最大使用圧力は 300 気圧であり \pm 5 気圧に制御された高圧気体はここで約 0.5 気圧以内 に精密制御される. 飽和器 $(\mathrm{H})$ および予備飽和器 (G) は Fig. 2 に示すようなまったく同じ構造のもので，ス テンレス製高圧パイプと高圧継手のみを使用して作製し た. 容器の中にはガラス玉を入れ，接触面積を増加させ ると同時に飛沫同伴防止に用いた．逆流防止用の高圧容 器 $(\mathrm{F})$ には飽和器と基本的に同じものを流れの向きを反 対にして使用した．高圧バルブ (a) には三方ボールバル ブ (Whitey 社製)を使用した。 また膨張バルブ (b) に は同じくWhitey 社製の精密微量調節バルブを用いた. 高沸点成分用サンプラー (I) には Nitta-Moore 社製 の透明高圧パイプを使用し，氷浴 $(\mathrm{K})$ 中に設置した. 高圧ガスを採取するための高圧容器 $(\mathrm{J})$ は液体 $\mathrm{N}_{2}$ 浴 (L) 中に执かれている.

平衡圧力は Ruska 社製の実荷重圧力計で検定した長 野計器製ブルドン管式精密圧力計 (E) で測定し，その測 定精度は $1 / 1000$ 以内であった.

重量分析に用いた天科は長計量器製の大型直示天科 で, $3000 \mathrm{~g}$ までの重量を $0.1 \mathrm{mg}$ まで感知することが でき, 分析の再現性は $\pm 0.3 \mathrm{mg}$ 以内であった.

Fig. 1 中破線で示した水恒温槽部は比例制御により $\pm 1 / 100^{\circ} \mathrm{C}$ 以内に制御され，宝工業社製 $\mathrm{D}-641$ 温度計 により $\pm 1 / 100^{\circ} \mathrm{C}$ の精度で測定した（温度は IPTS-68 


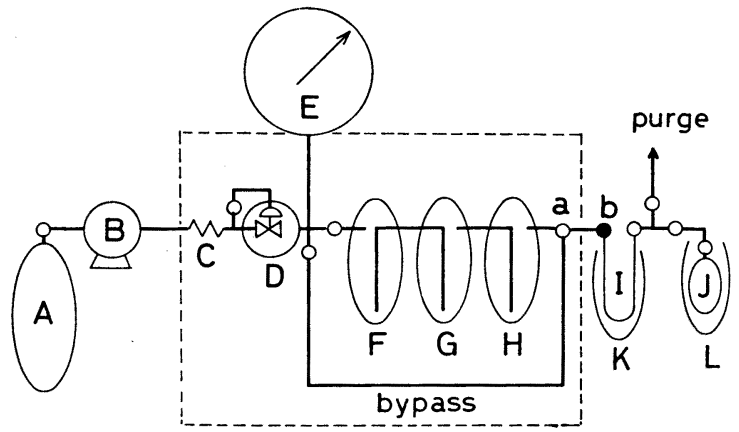

Fig. 1 Schematic diagram of experimental apparatus A: Gas cylinder, B: High pressure pump, C: Heat exchanger, D: Pressure regulator, E: Bourdon tube gage, F: Discriminating cut-out, G: Pre-saturator, H: Saturator, I: Sampler for heavy component, J: Solvent sampler, K: Ice bath, L: Liquid- $\mathrm{N}_{2}$ bath, a: Three-way ball valve, $b$ : Regulating valve

による）.

高圧ガス容器から液体状態で送られた溶媒成分はまず 高圧ポンプにより加圧され, 設定平衡圧力より $5 \sim 10$ 気 圧程度高い王力で圧力調整器に供給される．圧縮液体は 圧力調整器に送り込まれる前に熱交換器 (C) に入り, $40^{\circ} \mathrm{C}$ の時は超臨界流体として，また $25^{\circ} \mathrm{C}$ では高圧液 体として送り込まれる. 圧力調整器で設定圧力に調整さ れた高圧流体は逆流防止容器, あらかじめ溶質成分を仕 込んでおいた予備飽和器および飽和器を通り三方バルブ (a) まで導入され平衡に到達するまで $1 \sim 2$ 時間放置す る.この間に純粋溶媒をバイパス回路から三方バルブを 通って膨張バルブまで導入させる．以上の操作で央験準 備が完了する.なぜ純粋溶媒をバルブ (a) から膨張バル ブ (b) まで充填するのかについては後述する.

実験開始と同時に三方バルブの向きをかえ飽和器と膨 張バルブとを連結させ, 膨張バルブを所定の流速が得ら れるように微調節する．本実験では流速の影響による平 衡状態の破壊および飛沫同伴等を考慮して，一定の低流 速 (20 100 [ $\mathrm{cm}^{3}$ (normal state)/min.]) で操作した. 特に実験開始直後の三方バルブを開くことによる流れの 乱れを防止することは重要であり，したがって純粋溶媒 を前もってバルブ (a)〜 (b) 間に充填しておき安定な流れ を得るよう工夫した．また本実験低流速域では流速の影 響による平衡状態の乱れがほとんど無いことを確認し た. 平衡状態の混合流体が膨張バルブを通過すると急激 に圧力が大気圧以下に減圧され，溶解度が急減するた め, 溶質成分はサンプラー (I) 内で固体として析出す る.この際，析出した高沸点成分の流出を防ぐ目的でサ ンプラーは水浴中に設置し，同時にサンプラー内の流れ の状態を肉眼で観察した。

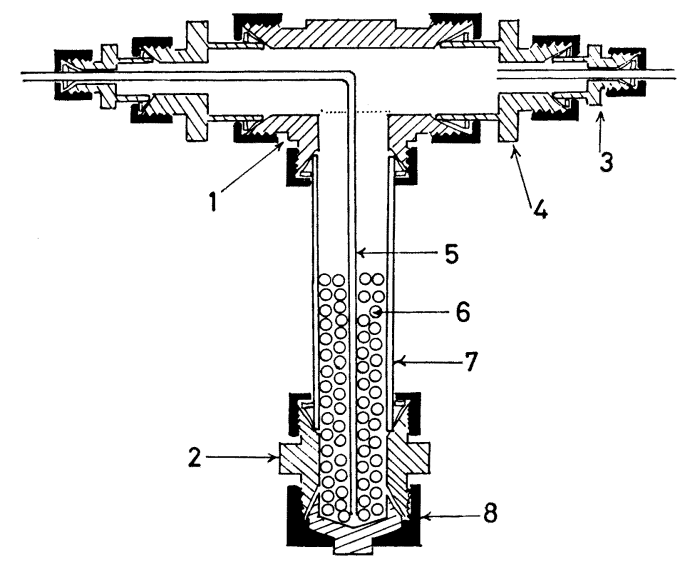

Fig. 2 Scheme of saturator

1: T-shape union (3/4"), 3: Straight union $\left(3 / 4^{\prime \prime}\right), 3$ : Shoulder removed reducer $\left(3 / 8^{\prime \prime}-\right.$ $\left.1 / 8^{\prime \prime}\right)$, 4 : Reducer $\left(3 / 4^{\prime \prime}-3 / 8^{\prime \prime}\right)$, 5: Tube $\left(1 / 8^{\prime \prime}\right)$, 6: Glass beads, 7 : Pipe $\left(3 / 4^{\prime \prime}\right), 8$ : Cap $\left(3 / 4^{\prime \prime}\right)$

溶質成分を完全に放出した溶媒成分は液体 $\mathrm{N}_{2}$ 中に設 置された高圧容器 $(\mathrm{J})$ に採取される. 数時間後, バルブ (a), (b) を同時に閉じ, 高圧容器 (J)を取りはずして溶 媒成分を科量する．その後再びバルブ (b) のみを開け， バイパス回路を通じて溶媒成分を流出させバルブ (a) (b) 間に少し残っている溶質成分をサンプラー (I) に送 り出し, 同じく溶質成分を科量する. この際, 溶媒成分 はすべて放出させることにより, 前もってこの空間に充 填しておいた純粋溶媒量を差し引くことができる. 特に 溶媒成分として $\mathrm{CO}_{2}$ を用いる場合，バルブ (b) 内でド ライアイスが生成するのを防ぐため，この周囲はリボン ヒーターで加熱する必要がある．そうするとバルブ (b) の手前で高圧流体は平衡温度より高くなって溶質溶解度 が減少し, バルブ (a) (b) 間で溶質成分の一部が析出 する可能性もあり，したがってこの空間の掃除は再現性 のあるデータを得るために必要な操作である.

試薬

溶媒成分として使用した $\mathrm{CO}_{2}$ は製鉄化学工業 (株) 製 の純度 $99.99 \mathrm{~mol} \%$ 以上のものであり, エタンは高千 穂化学社製の純度 $99.7 \mathrm{~mol} \%$ 以上のものを使用した. 溶質成分であるオクタデカンは和光純薬工業社製特級99 mol\% 以上のものを使用した. いずれの試薬も精製し ないでそのまま用いた。

\section{2. 実験 結 果}

オクタデカンー $\mathrm{CO}_{2}$ 系およびオクタデカンーエタン 系の測定結果をそれぞれ Table 1 と Table 2 に示す. それぞれの Table 中 $P y_{1} / P_{1} \mathrm{~s}$ は enhancement factor と呼ばれ，その温度における純粋溶質成分の飽和蒸気圧 に対する同じ温度のある王力に括ける混合流体中での溶 


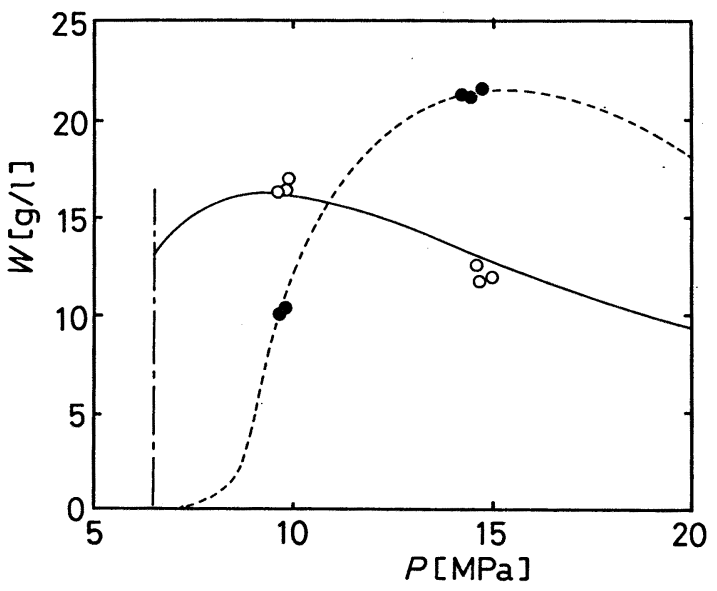

Fig. 3 Solubilities of octadecane in compressed $\mathrm{CO}_{2}$ at $25^{\circ} \mathrm{C}$ and $40^{\circ} \mathrm{C}$

○: expl. $25^{\circ} \mathrm{C}, 0$ : expl. $40^{\circ} \mathrm{C},-$ : calc. $25^{\circ} \mathrm{C}$, ---: calc. $40^{\circ} \mathrm{C}$, ___ _ coexistence

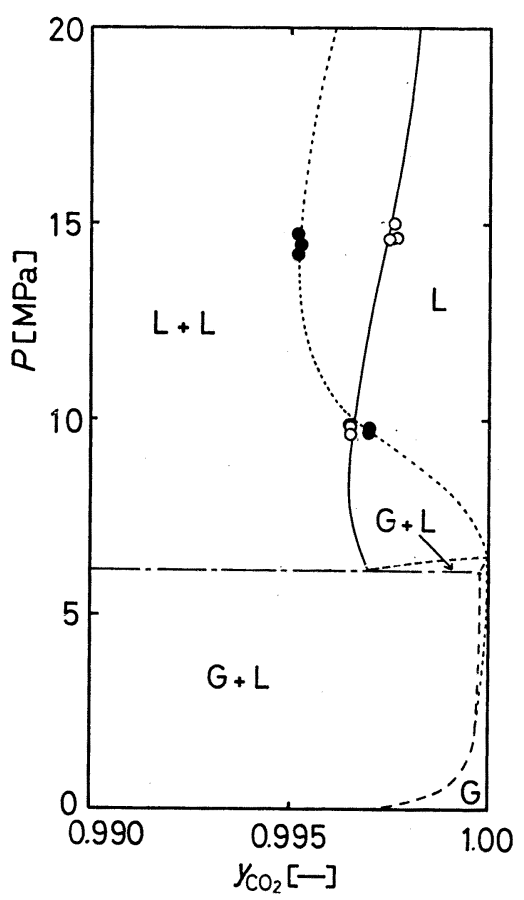

Fig. $4 P-y$ isotherms for octadecane- $-\mathrm{CO}_{2}$ system at $25^{\circ} \mathrm{C}$ and $40^{\circ} \mathrm{C}$

○: expl. $25^{\circ} \mathrm{C}$, : expl. $40^{\circ} \mathrm{C},-$ : calc. $25^{\circ} \mathrm{C}$, -..--: calc. $40^{\circ} \mathrm{C}$

質成分の分圧の比で定義される.なお，オクタデカンの 飽和蒸気圧は Macnick-Prausnitz ${ }^{3)}$ の実験相関式から 求めた.この時のオクタデカンの融点 $\left(28.2^{\circ} \mathrm{C}\right)$ より低 い $25^{\circ} \mathrm{C}$ の場合飽和蒸気圧とは呼べないが相関式を外挿 して求めた.

混合流体 $1000 \mathrm{~cm}^{3}$ 当りにオクタデカンが何グラム溶
Table 1 Mole fraction and enhancement factor of octadecane (1) in compressed $\mathrm{CO}_{2}(2)$

\begin{tabular}{|c|c|c|c|c|}
\hline $\begin{array}{c}T \\
{\left[{ }^{\circ} \mathrm{C}\right]}\end{array}$ & $\begin{array}{c}\boldsymbol{P}_{1}^{\mathrm{s}} \\
{[\mathrm{MPa}]}\end{array}$ & $\stackrel{P}{\boldsymbol{P}}$ & {$\left[-y_{1}\right]$} & $\begin{array}{c}P y_{1} / P_{1} \mathrm{~s} \\
{[-]^{s}}\end{array}$ \\
\hline \multirow{6}{*}{25} & \multirow{6}{*}{$2.59 \times 10^{-8 *}$} & 9.63 & $3.47 \times 10^{-3}$ & $1.26 \times 10^{6}$ \\
\hline & & 9.82 & $3.47 \times 10^{-3}$ & $1.32 \times 10^{6}$ \\
\hline & & 9.87 & $3.59 \times 10^{-3}$ & $1.37 \times 10^{6}$ \\
\hline & & 14.62 & $2.49 \times 10^{-3}$ & $1.41 \times 10^{6}$ \\
\hline & & 14.64 & $2.32 \times 10^{-3}$ & $1.31 \times 10^{6}$ \\
\hline & & 15.03 & $2.35 \times 10^{-3}$ & $1.37 \times 10^{6}$ \\
\hline \multirow{6}{*}{40} & \multirow{6}{*}{$1.33 \times 10^{-7}$} & 9.66 & $2.90 \times 10^{-3}$ & $2.11 \times 10^{5}$ \\
\hline & & 9.66 & $2.89 \times 10^{-3}$ & $2.11 \times 10^{5}$ \\
\hline & & 9.76 & $2.91 \times 10^{-3}$ & $2.14 \times 10^{5}$ \\
\hline & & 14.24 & $4.77 \times 10^{-3}$ & $5.11 \times 10^{5}$ \\
\hline & & 14.45 & $4.72 \times 10^{-3}$ & $5.14 \times 10^{5}$ \\
\hline & & 14.73 & $4.79 \times 10^{-3}$ & $5.28 \times 10^{5}$ \\
\hline
\end{tabular}

* Extrapolated value

Table 2 Mole fraction and enhancement factor of octadecane (1) in compressed ethane (2)

\begin{tabular}{|c|c|c|c|c|}
\hline $\begin{array}{c}T \\
{\left[{ }^{\circ} \mathrm{C}\right]}\end{array}$ & $\begin{array}{c}P_{1} \mathrm{~s} \\
{[\mathrm{MPa}]}\end{array}$ & $\begin{array}{c}P \\
{[\mathrm{MPa}]}\end{array}$ & {$[-]$} & $\begin{array}{c}P y_{1} / P_{1} \mathrm{~s} \\
{[-]^{1}}\end{array}$ \\
\hline \multirow{4}{*}{25} & \multirow{4}{*}{$2.59 \times 10^{-8 *}$} & 6.98 & $2.75 \times 10^{-2}$ & $7.39 \times 10^{6}$ \\
\hline & & 7.09 & $2.83 \times 10^{-2}$ & $7.70 \times 10^{6}$ \\
\hline & & 9.97 & $2.99 \times 10^{-2}$ & $1.15 \times 10^{7}$ \\
\hline & & 10.23 & $2.94 \times 10^{-2}$ & $1.15 \times 10^{7}$ \\
\hline \multirow{3}{*}{40} & \multirow{3}{*}{$1.33 \times 10^{-7}$} & 5.08 & $2.63 \times 10^{-4}$ & $1.01 \times 10^{4}$ \\
\hline & & 5.13 & $2.59 \times 10^{-4}$ & $1.00 \times 10^{4}$ \\
\hline & & 5.13 & $2.69 \times 10^{-4}$ & $1.04 \times 10^{4}$ \\
\hline
\end{tabular}

* Extrapolated value

解しているのかをオクタデカンー $\mathrm{CO}_{2}$ 系を例としてと りあげ Fig. 3 に示す. 図中白丸が $25^{\circ} \mathrm{C}$, 黒丸が $40^{\circ} \mathrm{C}$ の実測值であるが，いずれの温度でも最大溶解度を持 ち, $25^{\circ} \mathrm{C}$ では約 $9 \mathrm{MPa}$ また $40^{\circ} \mathrm{C}$ では $15 \mathrm{MPa}$ 付近 でそれぞれ最大值を与える。なお， $25^{\circ} \mathrm{C}$ の実線および $40^{\circ} \mathrm{C}$ の破線は後述する Soave-Redlich-Kwong 状態 方程式 ${ }^{4)}$ (以後 SRK 状態式と省略する) による推算結 果である. $25^{\circ} \mathrm{C}$ では同じ圧力に扎いてオクタデカンー エタン系にはオクタデカンー $\mathrm{CO}_{2}$ 系の約 $4 \sim 5$ 倍程度 の溶解度 $\left(\mathrm{g} / \mathrm{cm}^{3}\right)$ を与える.

さらに SRK 状態式による相関結果からみると, それ ぞれの系におけるオクタデカンの enhancement factor の值は, $7 \mathrm{MPa}$ 付近に気液の臨界点を持つオクタデカ ン一エタン系の $40^{\circ} \mathrm{C}$ を除いて, オクタデカンーエタン 系の $25^{\circ} \mathrm{C}$ で約 $3 \times 10^{7}$, オクタデカンー $\mathrm{CO}_{2}$ 系の $25^{\circ} \mathrm{C}$ および $40^{\circ} \mathrm{C}$ でそれぞれ $1.5 \times 10^{8}, 6 \times 10^{5}$ の值に収れ んした.

\section{3. 結果および考察}

本研究では, 溶媒成分の臨界温度および溶質成分の融 点をはさんだ $25^{\circ} \mathrm{C}, 40^{\circ} \mathrm{C} に$ に打る相平衡関係を実測 したことから, 得られた平衡データが固気, 固液, 気液, 液液いずれの平衡関係に対応するものなのかを知る必要 


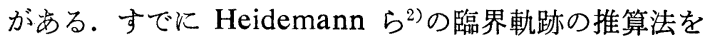
SRK 状態式に適用し, 種々の炭化水素を含む混合系の 臨界軌跡を満足に表現できることを以前報告した ${ }^{1)}$ 。例 えば $\mathrm{CO}_{2}$ 一炭化水素混合系の場合, トリデカンより長 鎖の炭化水素を含む系の臨界軌跡は, 炭化水素の臨界点 から出発する気液臨界軌跡が液液臨界軌跡と連結し, 一 方 $\mathrm{CO}_{2}$ の臨界点からの気液臨界軌跡が臨界終点で消失 すること等をその中で述べた。本研究でも同様な方法に より各混合系の臨界軌跡を推算し, 本実験の平衡関係が ぞんな異相間で成立しているかについて考察を行った. そして気相および液相に対しては SRK 状態式を，また 固相に対しては現実に即した仮定を導入することにより 実験データの相関を試みた。

\section{$3 \cdot 1$ オクタデカン一 $-\mathrm{CO}_{2}$ 系}

本系の臨界軌跡の特徵は, まず $\mathrm{CO}_{2}$ の臨界点から出 発した気液臨界軌跡が液液共存領域に衝突して消失する こと(上部臨界終点を持つ), 次にオクタデカンの臨界 点から出発するもら一方の気液臨界軌跡はそのまま液液 共存面に移行し, 液液臨界軌跡と連続してさらに高圧へ と進んでいる点にある.したがって実験圧力を考虑すれ ば $25^{\circ} \mathrm{C}$ の本実験の測定データは液液平衡関係に対応し ているるのと考光られる. 一方 $\mathrm{CO}_{2}$ の臨界点から出発 した気液臨界軌跡の消失点が, $40^{\circ} \mathrm{C}$ よりわずかに低温 であることから, 本実験の $40^{\circ} \mathrm{C}$ の等温線は気液平衡関 係を示すと考えられる。

以上より，オクタデカンー $\mathrm{CO}_{2}$ 系の $25^{\circ} \mathrm{C}$ およ゙ $40^{\circ} \mathrm{C}$ の実験結果がそれぞれ液液掞よび気液の平衡関係 に対応するものと想定して SRK 状態式を両相に適用す ることにより実験データの相関を試みた。一般的な相平 衡相関の手法により両温度に打ける実験結果を SRK 状 態式中の二成分系定数 $k_{12}$ を用いて相関したところ $25^{\circ} \mathrm{C}$ では $k_{12}=0.125$ ，また $40^{\circ} \mathrm{C}$ では $k_{12}=0.128$ と なり, 二成分系定数の温度依存性も小さく, 満足に相関 できた．相関結果は Fig. 4 亿示す. 図中実線および破 線はそれぞれ $25^{\circ} \mathrm{C}, 40^{\circ} \mathrm{C}$ の SRK 状態式による計算 結果である.

\section{$3 \cdot 2$ オクタデカン一エタン系}

オクタデカンーエタン系の臨界軌跡を推算すると, エ タンの臨界点から出発した気液臨界軌跡が圧力の極大值 を通過した後そのままオクタデカンの臨界点まで連続し た軌跡となる.したがって，オクタデカンの融点より低 温の $25^{\circ} \mathrm{C}$ の実験結果は固液平衡に対応し, $40^{\circ} \mathrm{C}$ にお ける測定結果は気液平衡に対応しているものと考兄られ る.

固液平衡関係を状態式で相関，推算する場合，固相側 を純粋とし，液相側に状態式を適用する方法が一般的で ある.この場合熱力学的な平衡条件より次式が得られる.

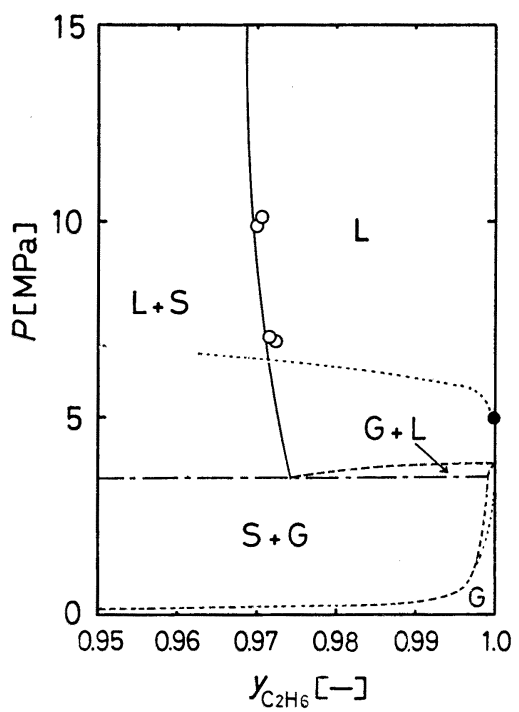

Fig. $5 \quad P-y$ isotherms for octadecane-ethane system at $25^{\circ} \mathrm{C}$ and $40^{\circ} \mathrm{C}$ O: expl. $25^{\circ} \mathrm{C}$, : expl. $40^{\circ} \mathrm{C},-$ : calc. $25^{\circ} \mathrm{C}$, -.-.-: calc. $40^{\circ} \mathrm{C}$

$$
x_{1}{ }^{(\mathrm{L})}=P_{1}^{\mathrm{s}} \exp \left[v_{1}\left(P-P_{1}^{\mathrm{s}}\right) / R T\right] / \varphi_{1}{ }^{(\mathrm{L})} P
$$

ただし， $x_{1}{ }^{(\mathrm{L})}, \varphi_{1}{ }^{(\mathrm{L})}$ はそれぞれ液相に和けるオクタデカ ンのモル分率, および fugacity 係数であり, $v_{1}, P_{1}{ }^{\mathrm{s}}$ は それぞれの温度に拄ける固体オクタデカンのモル容積お よび昇華圧力である、 $v_{1}$ は压力によらず一定とし，また $P_{1}{ }^{\mathrm{s}}$ は十分低いので $P_{1}{ }^{\mathrm{s}}$ に括ける気体のオクタデカンは 理想気体と仮定した。したがって SRK 状態式を液相に 適用して fugacity 係数 $\varphi_{1}{ }^{(\mathrm{L})}$ を計算すれば Eq. (1) に よって液相側のオクタデカンのモル分率が求まる. $25^{\circ} \mathrm{C}$ の測定データを表現するように SRK 状態式中の二成分 系定数 $k_{12}$ を決定したところ $k_{12}=0.099$ となった. 計 算結果は Fig. 5 亿示す. 図中 G $+\mathrm{L}$ で示す付加的な気 液共存領域および $\mathrm{S}+\mathrm{G}$ の固気共存領域の平衡曲線は, わかりやすいように模式的に描いている. 実験値と計算 值の一致からみて, 計算に用いた近似および仮定はほぼ 妥当なるのであると思われる。なお固液平衡のかわりに 気液拉よび液液平衡関係を想定して同じく $25^{\circ} \mathrm{C}$ の結果 を相関することを試みたが実験結果を表現することはで きなかった。

一方 $40^{\circ} \mathrm{C}$ の場合気液平衡関係の測定に対応している ものと想定して, 結果に対し直接 SRK 状態式による相 関を行った. 最適な $k_{12}$ の值は $k_{12}=0.056$ となり $25^{\circ} \mathrm{C}$ の時の值とかなりの相違を示した。すた $40^{\circ} \mathrm{C}$ における 混合物の臨界圧力はほぼ $7 \mathrm{MPa}$ 程度と比較的低い。7 $\mathrm{MPa}$ 付近の相平衡関係の実測を試みたが，混合物の臨 界点近傍に打ける独特な現象, 液相容積の急激な増加, 気液両相の密度差が非常に小さくなる等, やはり流通式 
では測定が困難であり，再現性のあるデータは得られな かった. $40^{\circ} \mathrm{C}$ に拈ける SRK 状態式の気液平衡の計算 結果は Fig. 5 中破線で示す. $40^{\circ} \mathrm{C}, 5 \mathrm{MPa}$ 付近のオ クタデカンの溶媒中の平衡組成は非常に小さく, 同じ圧 力での $25^{\circ} \mathrm{C}$ の平衡組成と比較すると約 $1 / 100$ となり急 激な溶解度の減少が見られた。

\section{結言}

本研究では $\mathrm{CO}_{2}$ およびェタンを溶媒成分とし，オク タデカンを溶質成分とした沸点差の非常に大きい非対称 系の高圧相平衡関係を $25^{\circ} \mathrm{C}$ と $40^{\circ} \mathrm{C}$ で実測した。 こ の温度は溶媒成分に対してはその臨界温度をはさんだ上 下であり，同時に溶質成分に対しては融点の前後に対応 する.この実験結果に対する検討とから以下のような考 察を得た。

1）臨界温度より低温および高温の高圧流体に対する 高沸点成分の溶解度の比較では必ずしも超臨界温度にお ける高圧流体への溶解度が大きいわけではなく，むしろ ある圧力範囲では逆の現象が生じている.

2) 固相をも含む極めて非対称性の大きい混合系の相 平衡関係は非常に複雑であり，得られた測定点がどのよ らな異相間の平衡関係に対応するのかを知ることは，デ 一タの相関，推算に必要不可欠である，その意味で混合 系の臨界軌跡からの情報は極めて有益である.

[謝 辞] 実験に際して協力を得ました敦田孝史君
(現大阪大学大学院生)に感謝致します。本研究は文部省 科学研究費の援助を受けた。

\section{Nomenclature}

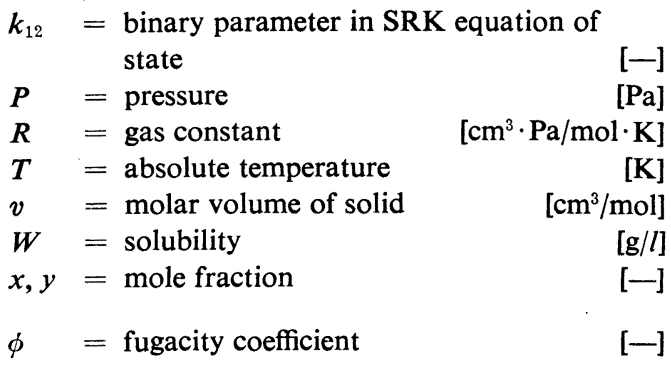

〈Subscripts〉

1 = octadecane (solute)

$2=$ solvent

〈Superscripts〉

(L) = liquid phase

$\mathrm{s} \quad=$ saturated state

\section{Literature cited}

1) Haniu, H., H. Takata, H. Nishii, K. Ohgaki and T. Katayama: Preprints for Meeting of The Soc. of Chem. Eng., Japan, Himeji, 65 (1982).

2) Heidemann, R. A. and A. M. Khalil: AIChE J., 26, 769 (1980)

3) Macnick, A. B. and J. M. Prausnitz: J. Chem. Eng. Data, 24, 175 (1979).

4) Soave, C.: Chem. Eng. Sci., 27, 1197 (1972).

(1983 年 7 月 1 日受理)

\title{
High-Pressure Phase Equilibria for Octadecane- $\mathrm{CO}_{2}$ and Octadecane-Ethane Systems at $25^{\circ} \mathrm{C}$ and $40^{\circ} \mathrm{C}$
}

\author{
Kazunari Ohgaki, Itsuro Tsukahara and Takashi Katayama \\ Dept. of Chem. Eng., Osaka Univ., Toyonaka, 560
}

\begin{abstract}
Key Words: Phase Equilibrium, Supercritical Extraction, Carbon Dioxide, Ethane, Octadecane, High Pressure, Solubility, Thermodynamics

Phase equilibria for the two binary systems octadecane- $\mathrm{CO}_{2}$ and octadecane-ethane were measured by use of a flow method at $25^{\circ} \mathrm{C}$ and $40^{\circ} \mathrm{C}$ for a fundamental study of supercritical fluid extraction.

The two experimental temperatures were subcritical and supercritical temperatures for each solvent of the systems, and they were also below and above the melting point for octadecane. Therefore, appearances of various phase equilibria such as solid-liquid, solid-gas, gas-liquid and liquid-liquid equilibria had to be taken into consideration.

It is examined from prediction of critical locus for each system which kind of equilibrium is corresponding to the phase equilibrium at each experimental condition. Thereafter, the phase-equilibrium data are satisfactorily correlated by use of the Soave-Redlich-Kwong equation of state.

There is a certain pressure range where the solubilities of octadecane to high pressure fiuids are suddently decreased by a small increase of temperature from subcritical to supercritical states.
\end{abstract}

